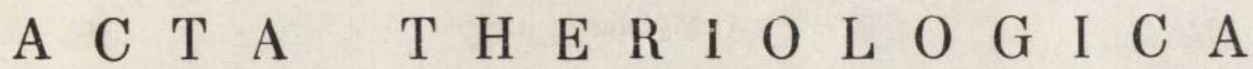 \\ VOL. XIV, 12: 161-166. \\ BIAŁOWIEŻA \\ 30.VIII. 1969
}

\author{
Andrzej MYRCHA, Lech RYSZKOW S I \\ \& Wiera W A L KOWA
}

\section{Bioenergetics of Pregnancy and Lactation in White Mouse*}

[With 2 Figs.]

\begin{abstract}
Changes of body weight during pregnancy and lactation as well as food ingested, assimilated and metabolizable energy were recorded. Pregnancy lasted on an average 19.6 days, mean number of born animals was 9.78 , and the mean body weight of newborn mouse was $1.14 \mathrm{~g}$. The total amount of metabolizable energy taken by the female in connection with pregnancy was $82.32 \mathrm{Kcal}$. Caloric value of litter was $10.704 \mathrm{Kcal}$, placenta $4.004 \mathrm{Kcal}$. The body weight increase of female itself was observed during pregnancy and lactation. Caloric value of one gram of wet weight of the placenta was $513.7 \mathrm{cal}$ and dry weight $6,306 \mathrm{cal} / \mathrm{g}$. The total amount of metabolizable energy additionally taken by female during 26 days of lactation amounted to $354.224 \mathrm{Kcal}$.
\end{abstract}

\section{MATERIAL AND METHOD}

The white mice, Mus musculus Linnaeus, 1758 used for the experiments were obtained from the stock kept at the Field Station of the Institute of Ecology, Polish Academy of Sciences, at Dziekanów Leśny. The females were kept separately after fertilisation (observation of copulation plug) in two connected metabolic cages of the kind described by $\mathrm{Szczy}$ g i e 1 \& $\mathrm{Z}$ i o m bs ki (1960). The two cages were connected by a corridor which could be closed. The female was kept in one of the cages until it gave birth. The young were kept with the mother up to the 10th day of life, after which the mother remained in one cage and the young in the second.

In order to allow the mother to nurse her young she was allowed to enter their cage every two hours during the day, and every five hours during the night. Food was supplied ad libitum in the form of the granulated MSL mixture (a brand of commercial food for mice in Poland), and also water.

* This study was carried out under the Small Mammal Project of the International Biological Programme in Poland.

11 - Acta theriol,

[161] 
The uneaten food, and also the faeces and urine, were carefully collected every 24 hours. Data from two consecutive days were used for calculation of food consumption and faeces and urine excretion.

The caloric value of food, faeces and urine was determined after drying to a constant weight in the presence of $\mathrm{CaCl}_{2}$ at a temperature of $60^{\circ} \mathrm{C}$ in a vacum drier, burning samples in a type KL-3 calorimeter of the Berthelot system. The urine was prepared by the $\mathrm{Nijkamp}$ (1965) method for burning. The caloric value of the placenta was determined by burning samples in a miniature bomb calorimeter described by Phillipson (1964).

Changes of energy requirements during pregnancy were observed in 14 females, and energy variations during lactation in 8 females.

\section{RESULTS}

\subsection{Pregnancy}

In the females examined pregnancy lasted on an average 19.6 days. The average body weight of a female on the first day of pregnancy was $21.0 \mathrm{~g}$. A marked increase in body weight attaining a value of $39.3 \mathrm{~g}$ $(87 \%)$ took place on the final days of pregnancy (Fig. 1).

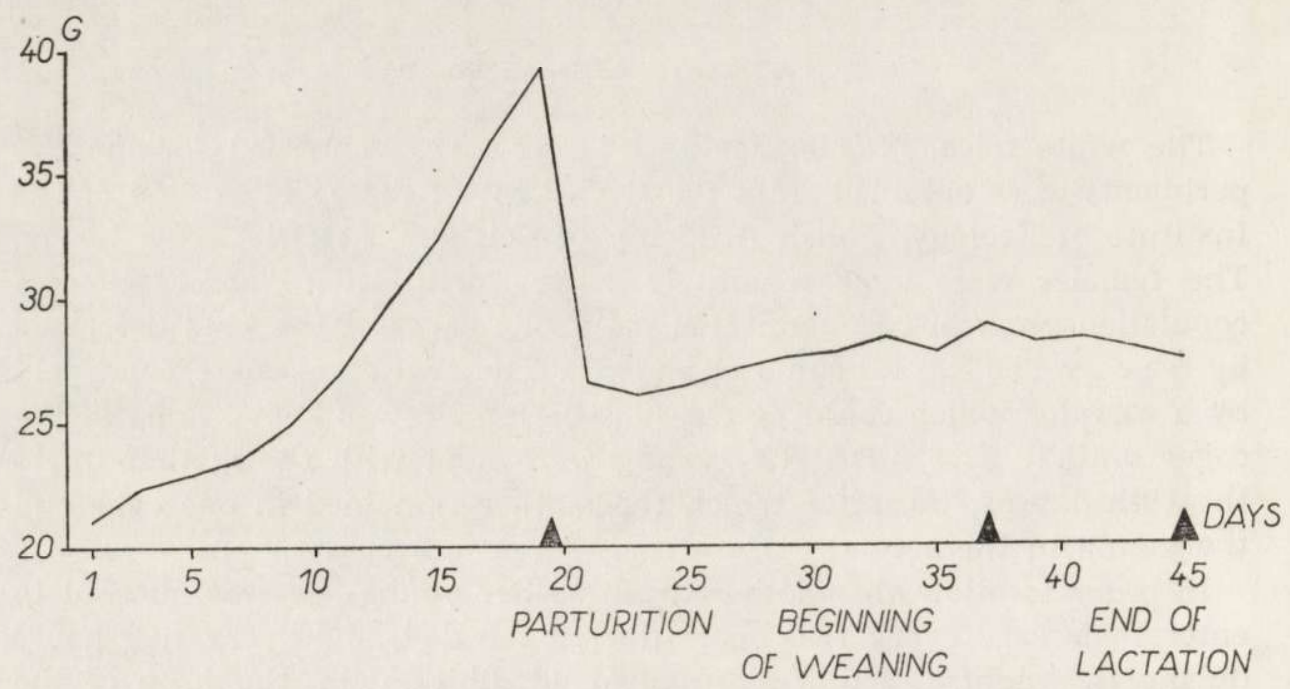

Fig. 1. Change of female boay weight during pregnancy and lactation.

The average number of mice born in a litter was 9.78 , and the mean body weight of newborn mouse, $1.14 \mathrm{~g}$. Hence the difference between increase in body weight of a pregnant female and weight of the newborn 
youngs was $7.1 \mathrm{~g}$. This difference is connected with increase in body weight of the female itself during pregnancy, the weight of the placenta and the foetal waters. The mean weight of a female immediately after birth was $26.5 \mathrm{~g}$, which indicates that in addition to the development of the embryos there was also a simultaneous increase in the female's body weight of $5.5 \mathrm{~g}$ (comparison of body weight of a female on the first day of pregnancy and body weight immediately after giving birth Fig. 1).

On the basis of the above data the weight of the placenta and foetal waters can be estimated to be $1.6 \mathrm{~g}$.

The caloric value of the food with which the mice were supplied was $4,161.9 \mathrm{cal} / \mathrm{g}$. Food consumption on successive days of pregnancy increased unevenly (Fig. 2). Maximum increase occurred on the last

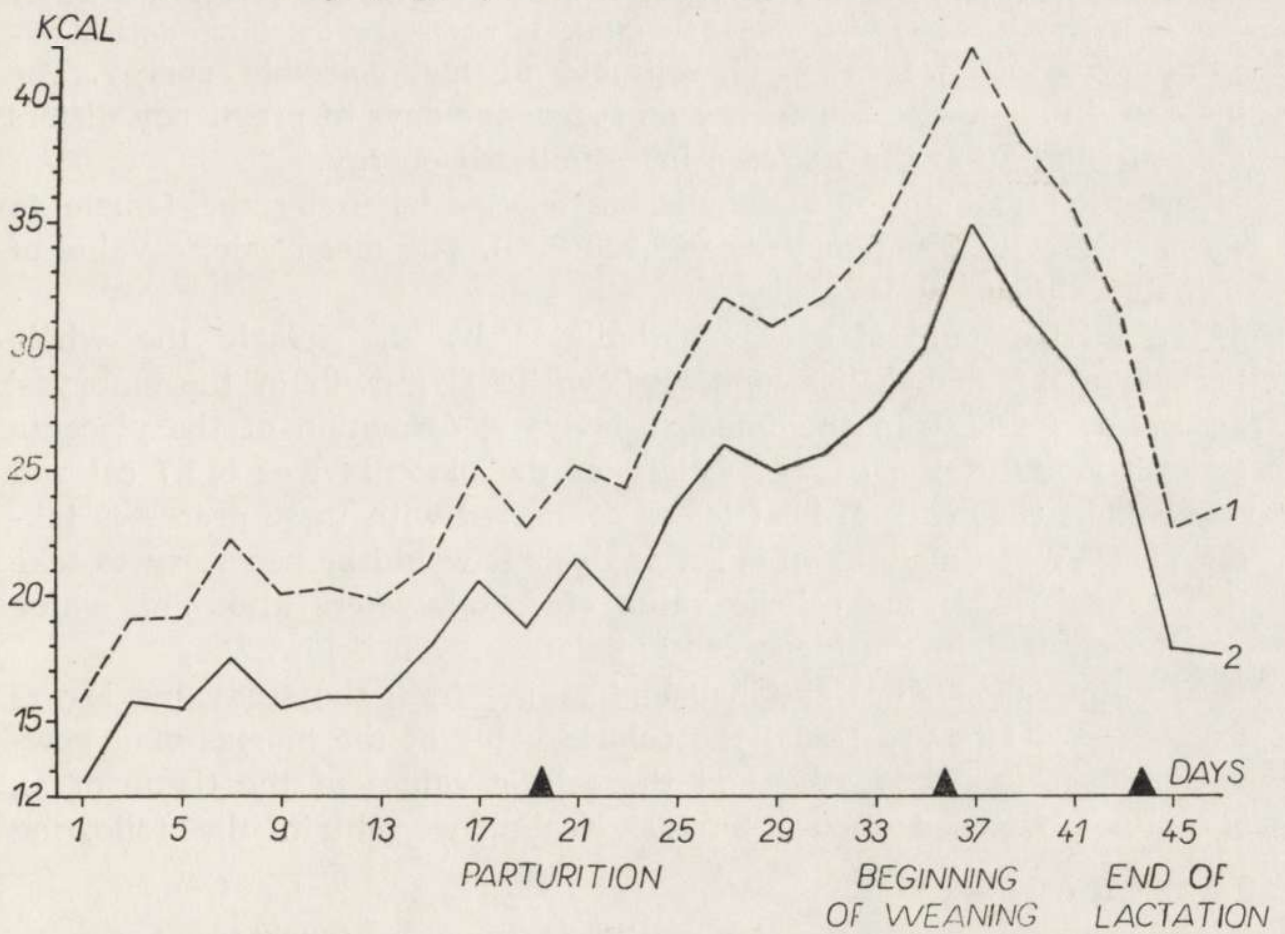

Fig. 2. Food ingested and asymilated energy during pregnancy and lactation (Kcal/female/24 hours).

days of pregnancy. The total food consumption of a female connected with pregnancy was $104.25 \mathrm{Kcal}$, which forms an increase of $33.6 \%$ in relation to its consumption, if the amount of food consumed had been maintained on the level of the first day of pregnancy.

By subtracting the caloric value of faeces from the caloric value of the food consumed we can estimate the amount of food assimilated by 
the animal. The mean caloric value of faeces was $4,244.0 \mathrm{cal} / \mathrm{g}$. The ratio of the amount of food assimilated to the food eaten defines the digestion coefficient.

Both during pregnancy and lactation the digestion coefficient exhibited small irregular variation. The average value of digestion coefficient was $81.4 \% \pm 0.82$.

Maximum increase assimilated energy occurred on the final days of pregnancy (Fig. 2). The total amount of food assimilated by the female during pregnancy, after subtracting the level of assimilated food corresponding to the first day of pregnancy, was $83.751 \mathrm{Kcal}$; that is, $4.276 \mathrm{Kcal}$ per female per day, which forms an increase of $33.8 \%$ in relation to the food assimilated on first day of pregnancy.

By subtracting the caloric value of urine from the caloric value of chodzą na powierzchnię wyławianą. Odległość ta wzrasta w kolejnych dniach wyassimilated food we obtain an estimate of metabolizable energy. The increase in metabolizable energy on successive days of pregnancy differs only slightly from the increase in assimilated energy.

The total amount of metabolizable energy taken by the female in connection with pregnancy was $82.320 \mathrm{Kcal}$. The mean caloric value of urine was $225.0 \mathrm{cal} / \mathrm{ml}$.

The total amount of energy assimilated by the female the whole period of pregnancy is connected with: 1) growth of the embryos' bodies; 2) increase in the female's body; 3 ) formation of the placenta (caloric value of $1 \mathrm{~g}$ of wet weight of the placenta was $513.7 \mathrm{cal}$ and dry weight $6306 \mathrm{cal}$ ); 4) heat losses connected with these processes taking place. When making an exact analysis it would be necessary to take into consideration the caloric value of foetal waters also. This value will be omitted in the bioenergetic balance given below.

Accepting the values obtained and taking from the study by $\mathrm{My} \mathrm{r}$ $\mathrm{cha} \& \mathrm{~W}$ a l k ow a (1968) the caloric value of the biomas of a newborn mouse as $0.96 \mathrm{Kcal} / \mathrm{g}$ and the caloric values of the tissue of an adult, not fattened mouse as $1.56 \mathrm{Kcal} / \mathrm{g}$, we obtain the following ballance:

Input Metabolizable energy $82.320 \mathrm{Kcal}$

Caloric value of:
litter
placenta
body increase of female
Total

Output

$10.704 \mathrm{Kcal}$ $4.004 \mathrm{Keal}$ $8.580 \mathrm{Kcal}$ $23.288 \mathrm{Kcal}$

Difference between input and output is due to heat produced during metabolism processes connected with production of litter and placenta as well as with increase in the body weight of the female. 


\subsection{Lactation}

The mean number of mice in a litter at birth was 9.78 , and up to the 26th day on which the experiment ended, an average of 3.57 individuals survived.

On the 26th day of live the mean weight of the young mice was $5.12 \mathrm{~g}$.

The amount of food consumed by the female during lactation was much higher than during pregnancy. A very rapid increase in the amount of food consumed took place up to the 37 th day, that is up to 17 th day of lactation (Fig. 2). After 17 days of lactation there is a decrease in the amount of food consumed by the female, which is connected with the young mice changing to independent feeding. On the 17th day of lactation females took in $19 \mathrm{Kcal}$ more in their food than they had eaten at the moment of giving birth.

The total amount of food additionally eaten by a female during 26 days of lactation was $458.562 \mathrm{Kcal}(17.637 \mathrm{Kcal}$ per animal/day), which forms an increase of $111.3 \%$ in relation to the first day of pregnancy.

The duration taken by changes in the amount of food assimilated (Fig. 2) and metabolizable energy was similar to the changes in the amount of food eaten.

The total amount of food additionally assimilated by the female during 26 days of lactation was $357.864 \mathrm{Kcal}$, and metabolizable energy was $354.224 \mathrm{Kcal}$.

The food requirements of a female increase slightly during pregnancy, whereas during lactation there is a rapid increase (Fig. 2). Similar results were obtained for Clethrionomys glareolus ( $\mathrm{S} \mathrm{ch} \mathrm{reber,1780)}$ by $\mathrm{Kaczmarski}(1966)$ and for Microtus arvalis (P a lla s, 1779) by Trojan \& Wojciechowska (1967).

During both pregnancy and lactation the coefficient of assimilation of food was maintained on the same level (81.4), hence increase in food requirements could be met by increase in the amount of food consumed. Growth of the alimentary tract during pregnancy and lactation made it possible to assimilate the increase amount of food consumed (M y r$\mathrm{ch} \mathrm{a}, 1965)$. One of the interesting results of these investigations is that during pregnancy there is also an increase in the body weight of the female itself, and not only of the embryo (Fig. 1). Females also increased in weight, although to a lesser degree, during lactation. In relation to the caloric value of the tissue of newborn mice $(10.7 \mathrm{Kcal})$ the caloric value of the placenta is considerable $(4.0 \mathrm{Kcal})$. 


\section{REFERENCES}

1. Kaczmarski F., 1966: Bioenergetics of pregnancy and lactation in the bank vole. Acta theriol., 11, 19: 409-417.

2. Myrcha A. \& Wa $1 \mathrm{kowa}$ W., 1968: Changes in the caloric value of the body during the postnatal development of white mice. Acta theriol., 13, 22: $391-400$.

3. Myrcha A., 1964: Variations in the length and weight of the alimentary tract of Clethrionomys glareolus (S c h re be r, 1780). Acta theriol., 9, 10: 139 -148 .

4. $\mathrm{Nijkamp} \mathrm{H.} \mathrm{J.,} \mathrm{1965:} \mathrm{Some} \mathrm{remarks} \mathrm{about} \mathrm{the} \mathrm{determination} \mathrm{of} \mathrm{the} \mathrm{heat} \mathrm{of}$ combustion and the carbon content of urina. [In: B la xter K. L., ed: "Energy metabolism «] Academic Press: 1-450. London-New York.

5. Phillipson J., 1964: A miniature bomb calorimeter for small biological samples. Oikos, 15, 1: 130-139.

6. Szczygiel A. \& Z i ombski H., 1960: Klatka do badań metabolicznych szczurów, Rocz-ki PZH: 9, 5: 461-467.

7. Trojan P. \& Wojciechowska B., 1967: Resting metabolism rate during pregnancy and lactation in the european common vole - Microtus arvalis (P a 11.). Ekol. pol. A, 15, 44: 811-817.

Received, January 6, 1969.

Instituty of Ecology,

Polish Academy of Sciences,

Warszawa, Nowy Swiat 72.

Andrzej MYRCHA, Lech RYSZKOWSKI i Wiera WALKOWA

\section{BIOENERGETYKA CIAZŻY I LAKTACJI MUS MUSCULUS}

Czternaście samic myszy laboratoryjnej po zapłodnieniu trzymano oddzielnie w specjalnie skonstruowanych klatkach. Po urodzeniu młodych pozostawiono 8 samic z dziećmi dla obserwacji. Młode trzymano razem z matką a po 10-ciu dniach życia izolowano je i dopuszczono do matki co 2 godziny w ciągu dnia i co 5 godzin w ciągu nocy. Co 24 godziny notowano: (1) ilość zjedzonego pokarmu, (2) ilość kału, oraz (3) ilość moczu wydalanego przez myszy.

Okres ciąży wynosił 19,6 dni. Wyraźny wzrost ciężaru ciała $(87 \%)$ następowal w ostatnich dniach ciąży (Ryc. 1). Przeciętna liczba myszy w miocie wynosiła 9,78 a ciężar noworodka $1,14 \mathrm{~g}$. Oprócz rozwoju embrionów następował równocześnie wzrost ciężaru ciała samicy. Ciężar łożyska i wód płodowych może być oszacowany na $1,6 \mathrm{~g}$.

Ilość zjedzonego pokarmu w okresie laktacji była znacznie wyższa niż w okresie ciąży (Ryc. 2). Największy wzrost konsumpcji pokarmu, energii zasymilowanej, oraz energii przemiennej występował w ostatnich dniach ciąży (Ryc. 2). Współczynnik strawności miał przeciętną wartość $81,4 \%$.

Bilans energetyczny myszy w okresie ciąży był następujący: energia metaboliczna (pobranie) - 82,320 Kcal; energia zużycia - 23,288 Kcal (z czego wypadało na: miot - 10,704 Kcal, łożysko - 4,004 Kcal, wzrost ciężaru ciała samicy $8.580 \mathrm{Kcal})$. 